\title{
Sciendo
}

Research Article

(C) 2018 Andrew Onwuemele. This is an open access article licensed under the Creative Commons Attribution-NonCommercial-NoDerivs License (http://creativecommons.org/licenses/by-nc-nd/3.0/).

\section{Public Perception of Flood Risks and Disaster Preparedness in Lagos Megacity, Nigeria}

\section{Andrew Onwuemele (Phd)}

Nigerian Institute of Social and Economic Research (NISER) Social and Governance Policy Research Department

Doi: 10.2478/ajis-2018-0068

\section{Abstract}

Flood risks are considered as one of the most devastating natural disasters. Presently, flooding occurs in all the ecological zones in Nigeria which has been linked to global warming. In Lagos Megacity, the incidence of flooding is now a reoccurring decimal which is only an indication of the failure of the existing mechanism for flood risk reduction. Knowledge of public perception of flood risk is considered a crucial element for a proactive preparedness for flood risk reduction. This study is aimed at gaining insight into the public perception of flood risks for proactive flood risks preparedness among residents in flood prone areas in Lagos megacity, Nigeria. The survey research design was utilized. Data were collected by questionnaire from residents of flood prone neighbourhoods in the city. The results show high awareness of flood risks among respondents that have experienced flooding previously than respondents that have not experienced flooding in the past. It also reveals poor preparedness among respondents that have not experienced flooding. The paper calls for public awareness creation among residents in flood prone areas of the city as a strategy to promote preparedness for flood disaster risks reduction in the city.

Keywords: Public perception; Flood Risks; Disaster Preparedness; Lagos Megacity; Nigeria

\section{Introduction}

Flood risks are one of the most significant threat to development effort of national and international government in terms of economic, physical and social losses (Jonkman, 2005). According to the UNISDR (2016), floods have accounted for 47 per cent of all weather-related disasters since 1995, affecting 2.3 billion people. Within this period, about 3,062 flood disasters incidences were recorded. Evidence from the literature confirmed that there were an average of 171 incidences of flood disasters between 2005 and 2014 from the initial 127 in the previous decades (UNISDR, 2016). It has been reported that each year, floods kill on the average 20,000 lives while at the same time affecting at least 20 million people worldwide (Smith and Petley (2009; Kellen et al., 2013).

Available evidence from the literatures indicate that losses emanating from flood hazards are likely to increase in the decades to come based on the IPCC 2007 predicted impacts of climate change (IPCC, 2007). Evidence also points to the fact that countries as well as household's vulnerability to incidence of flooding are expected to increase as a consequence of population growth and spatial expansion (Siegrist and Gutscher, 2006). In Nigeria, Lagos is one of the cities that is highly vulnerable to flooding. A recent study by World Bank economist, Stephane Hallegatte and colleagues in 2013 as reported in Business and Maritime West Africa (2013) ranked the city of Lagos $15^{\text {th }}$ among top 20 cities in terms of population exposed to coastal flooding, climate change 
and socio-economic change in the $2070 s^{1}$. In 2012, Lagos state government prepared the climate change adaptation strategy as part of the effort to reduce the impact of climate change particularly flooding in the state. In spite of this effort, flooding has continued to be a menace in the city.

Of recent, there is a general understanding among scholars that flood mitigation measures based solely on structural protection are unsustainable and have little effect in mitigating inundations and extreme floods on a permanent basis (Kundzewicz, 1999) ${ }^{2}$. This understanding has brought about a change in how planners and scholars alike deal with floods. One aspect of this change is the incorporation of public flood risks perception in the design of flood mitigation measures. The public perception of flood risk is now seen as one of the main components in flood risk management. It is therefore important to consider this key dimension in any effort to increase community preparedness. Previous flood risk management policies have been known to fail or be adversely affected when policy makers overlook public perception (Brown and Damery, 2002). Therefore, scholars have advocated that considering how the public perceive risk will improve success of flood risk management policies (Terpstra, 2010) ${ }^{3}$. This research explores the role of public perception of flood risk in disaster risks preparedness in Lagos megacity, Nigeria.

\section{Goal of the Study}

The goal of the paper is to explore the role of public perception of flood risks in disaster risks preparedness in Lagos megacity Nigeria. The specific objectives are to:

1. Determine the socio-economic characteristics of the respondents.

2. Determine the level of awareness of flood risks and experiences of flood risks among respondents in the study area.

3. Examine the linkage between flood risks awareness and the level of flood risks preparedness among respondents in the study area.

4. Proffer policy measures that will improve flood risks preparedness among the residents in Lagos Megacity.

\section{Study Area}

Lagos is one of Nigeria's thirty-six states. It was created on 27 May 1967 along with eleven others by the then Military Government. From 1861 to 1960, Lagos was a British colony and later became a Federal Capital between 1914-1991. The city is a low-lying wetland area in the south-western coastland of Nigeria. Lagos is bounded on the North and East by Ogun State and shares international boundary with the Republic of Benin in the West. To its South is the Atlantic Ocean where it has over $180 \mathrm{~km}$ stretch waterfront. The city occupies about $1,711.28$ square kilometres of the state's $3,577 \mathrm{~km}^{2}$ land mass. About 13 per cent of the city's land area is water. Lagos is built around a huge lagoon, with a mainland and three islands - Lagos, Ikoyi and Victoria. The dominant vegetation of the city consists of the freshwater and mangrove swamp forests with two climatic seasons: dry (November - March) and wet (April - October). The wettest months are between July and September. The state has a bimodal rainfall of $1,381 \mathrm{~mm}$ to $2,133 \mathrm{~mm}$ with average temperature of between 26 and 36 degrees Celsius. The population of Lagos city was estimated at 16.06 million as at December 2006, rose to 18.78 million in 2011 and it is projected to be 21.33 by $2015{ }^{4}$. Although, Lagos is no longer the administrative capital of Nigeria, it remains its commercial and industrial nerve centre. Lagos contributes about 40 per cent of Nigeria's non-oil GDP, and in 2007 has a per capita GDP of about US $\$ 2,555$, double the national figure (Onwuemele, 2015). ${ }^{5}$ Nonetheless, there is poverty in Lagos. Figure 1.1 shows the map of Lagos state.

\footnotetext{
${ }_{1}^{1}$ https://phys.org/news/2013-08-coastal-cities-losses.html

${ }^{2}$ https://www.nat-hazards-earth-syst-sci.net

${ }^{3}$ https://www.nat-hazards-earth-syst-sci.net

${ }^{4}$ Lagos Bureau of Statistics, 2010

${ }^{5}$ UNDP, 2009
} 


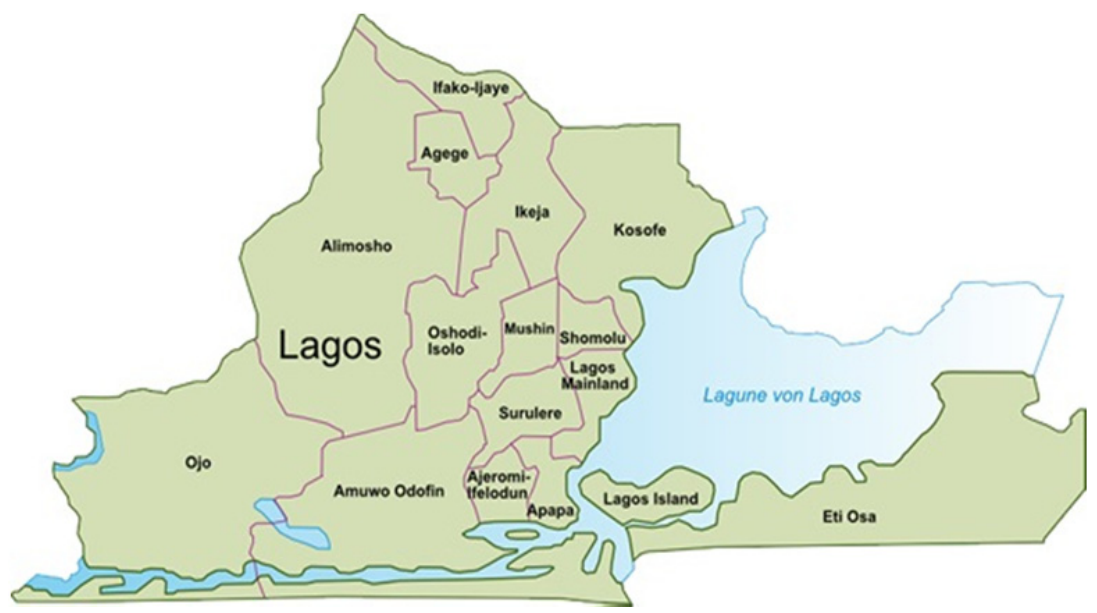

Figure 1.1: Map of Lagos State

\section{Materials and Methods}

The paper relies on primary data and were obtained from structured questionnaire administered to residents in flood prone communities. The questionnaire administration was carried out in purposively selected communities based on their vulnerability to flooding. The communities are Agiliti, Ikose-Ketu, Ajegunle, Owode Onirin and River view estate. Forty copies of questionnaire were administered in each community, making a total of 200 . The data collected from the questionnaire survey were analysed using appropriate statistical software and results were discussed with tables and figures generated from the analysis.

\section{Conceptual Framework}

Flood can be conceived as an emergence of large body of water over land areas not usually covered by water. In the context of the study area, flooding occurs mainly as a result of heavy downpours which in turn result in rise of the Atlantic Ocean (Adeoye, Ayanlade and Babatimehin, 2009). Floods risks are the result of meteorological and hydrological extremes which are mostly influenced by human factors. Although these influences are very diverse, they generally tend to aggravate flood hazards by accentuating flood peaks (Onwuemele, 2012). In the last decade, riskbased approaches are being adopted to 'manage' flood hazards. The term 'risk' is often used as a synonym for probability or chance.

In order to fully understand flood risks, it is crucial to be familiar with the different components that construct risks. Often risk is understood only superficially by equating it with the occurrence of an extreme event or hazard. While the occurrence of such a hazard is obviously the primary precondition, it is only one component in the creation of risk. The second component in the creation of risk is the fact that somebody or something has to be at risk; i.e. vulnerable to a hazard (WMO/WGP, 2008). Thus, Crichton (1999) defines risk as the probability of a loss, and this depends on three elements: hazard, vulnerability, and exposure. If any of these three elements in risk increase or decrease, then the risk increases or decreases respectively. On the other hand, exposure in the context of flood refers to the question of whether people or assets are physically in the path of flood waters or not. Vulnerability may be defined as the conditions determined by physical, social, economic, and environmental factors or processes, which increase the susceptibility of a community to the impact of hazards" (ISDR, 2004). In this context, flood risk can be conceived as the probability of the occurrence of flood hazard, exposure to the flood hazard, and of the susceptibility to flood hazard (Onwuenmele, 2012). Crichton (1999) conceives risk into the 
risk triangle where hazard is a function of both natural processes as well as anthropogenic environmental changes. On the other hand, Wilson (1990) conceives perception in terms of transforming input (e.g., flood warning) to output (e.g., mitigation response) while Slovic (2000) sees risk perception as the intuitive judgement of individuals and groups, Raaijmakers et al. (2008) defines risk in terms of relationship of three key factors, namely: awareness, worry and preparedness. He notes that in an event of increase in any of the factor or a combination of these factors raises the perception of risk and this contributes to enhanced flood resilience which will lead to decrease of worry and awareness over time (Figure. 1). Community awareness is, therefore critical and a sine qua non to effective and sustainable adaptation to flood risk.

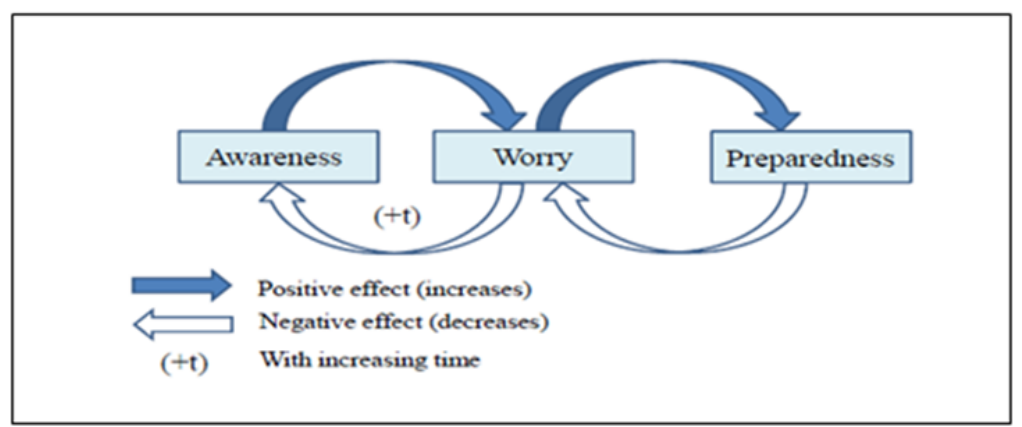

Figure. 1. Relationship between elements of risk perception Source: Raaijmakers et al., (2008).

\section{Results and Discussions}

The findings were analysed in terms of the Raaijmakers et al. (2008) concept of risk perception involving an exploration of risk awareness, worry and preparedness. But first, the paper shows the demographic and socio-economic characteristics of the respondents. Out of a total of 200 questionnaires administered to respondents, 195 were retrieved representing $97.5 \%$ response rate. Of these, the majority (82.5\%) were males. Also, $46.0 \%$ and $37.1 \%$ of the respondents were between the ages of 26-35 years and 36-45 years respectively. Also, the majority $(69 / 8 \%)$ of the respondents are married. About $45.1 \%$ and $42.0 \%$ had secondary and tertiary education respectively. However, only $8.0 \%$ of the respondents had no formal education.

\subsection{Awareness of Flood of Risks}

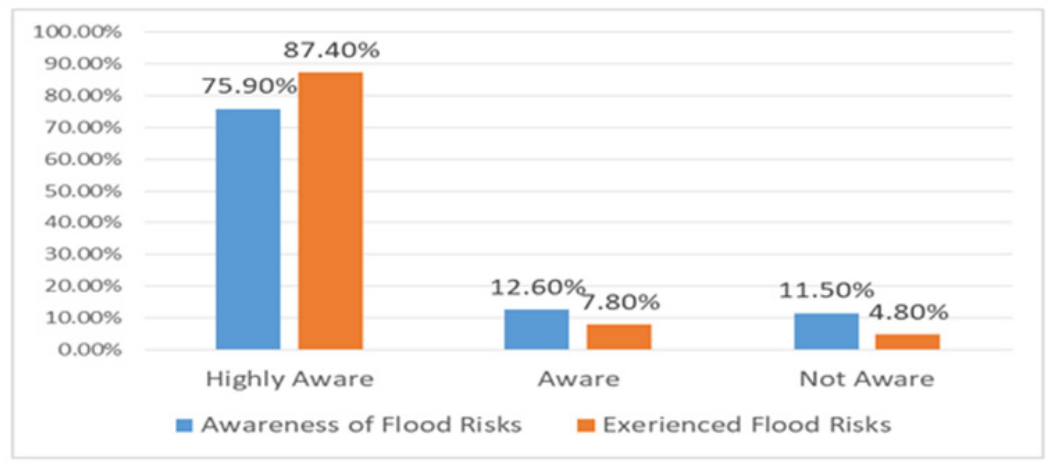

Figure 2: Awareness of Flood Risks and Experience of Flood Risks 
Figure 2 shows that the majority $(75.9 \%)$ of the respondents were aware of their exposure to flood risk. But more importantly, respondents that have previously experienced flooding were more aware of their exposure level to flood risks. For instance, 87.4 per cent of the respondents that have previously experienced flooding were highly aware of their exposure to flood risks. This finding is consistent with Pagneux et al., (2011) finding which indicates that previous experience of flooding is a key determinant of respondent's awareness of flood risks. The low awareness level of respondents that have not experienced flood risks have implication for flood risks mitigation. There is need for more awareness creation on the dangers of flood risks among the general public in the study area.

Figure 3: Awareness of Flood Risks and Educational Qualification

Figure 3 indicates that educational qualification of respondents was another major factor influencing awareness of flood risks as respondents with higher educational qualification show more awareness than respondents with lower educational qualification. For instance, 88.7 per cent of the respondents with tertiary educational qualification were aware of flood risks as against 45.5 per cent for respondents with no formal education. From the framework of analysis, worry was seen as one of the key determinants for preparedness. Findings from Figure 4 indicates that the majority $(96.8 \%)$ of the respondents were worried about being flooded. However, respondents that have experienced flooding previously were more worried of being flooded than others that have never experienced flooding. For instance, 87.4 per cent of respondents that have experienced flood risks were more worried of flood risks than those that have never experience

\subsection{Worry of Flood Risks}

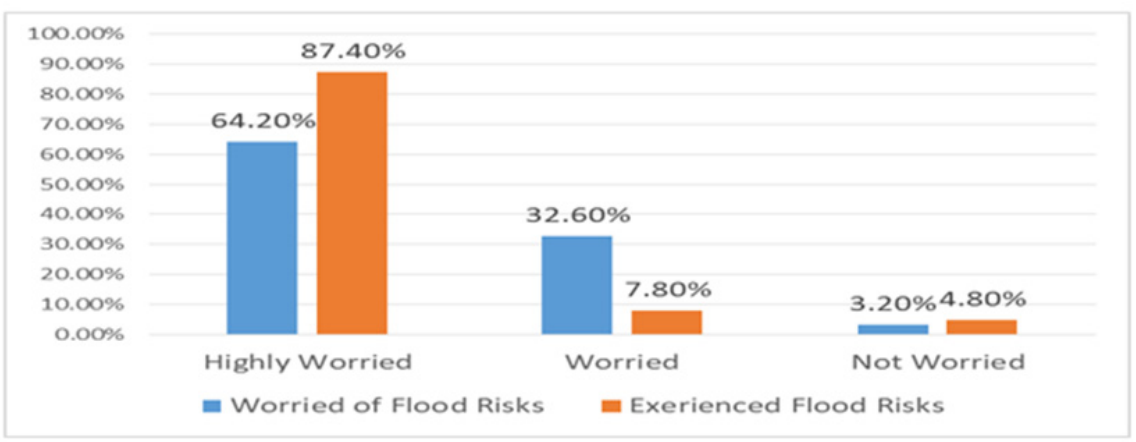

Figure 4: Worry of Flood Risks

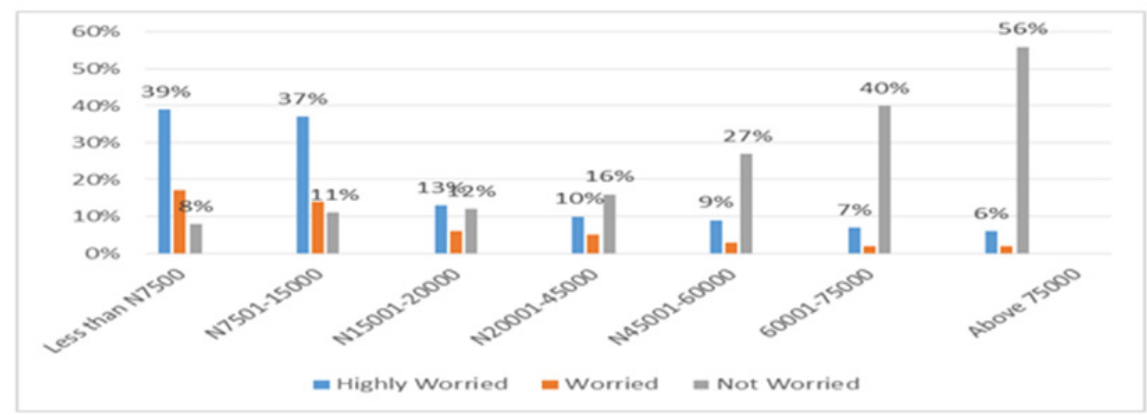

Figure 5: Income of Respondents and Degree of Worry of Flood Risks 
Figure 5 indicates that income of respondents plays a major role in influencing the level of worry. Respondents with high income level expresses less worry about flood risk disasters than respondents with lower income. This finding is in line with Hansen, (2005) finding which shows that higher income respondents worry less about the consequences of floods.

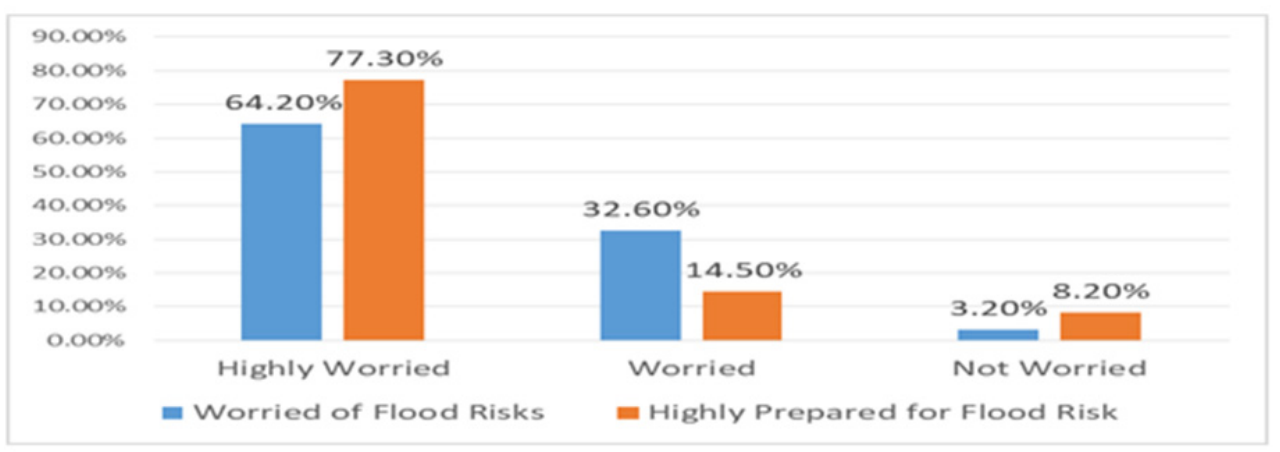

Figure 6: Degree of Worry and level of Preparedness

\subsection{Preparedness of Flood Risks}

Preparedness for disasters is critical for households, businesses, and communities. Disaster preparedness encompasses measures aimed at enhancing life safety when a flood risk disaster occurs. In this section of the paper, we examine the relationship among flood risks awareness, worry and disaster risks preparedness. Figure 6 indicates that disaster risks preparedness was higher for respondents that were more worried of flood risks disaster and low for respondents that were less worried. For instance, in the case of 64.20 per cent of respondents that were highly worried of flood risks, over 77 per cent of them were highly prepared for flood risks while in the case of 3.20 per cent of respondents that were not worried of flood risks, only 8.2 per cent of them were prepared for flood risks in their communities.

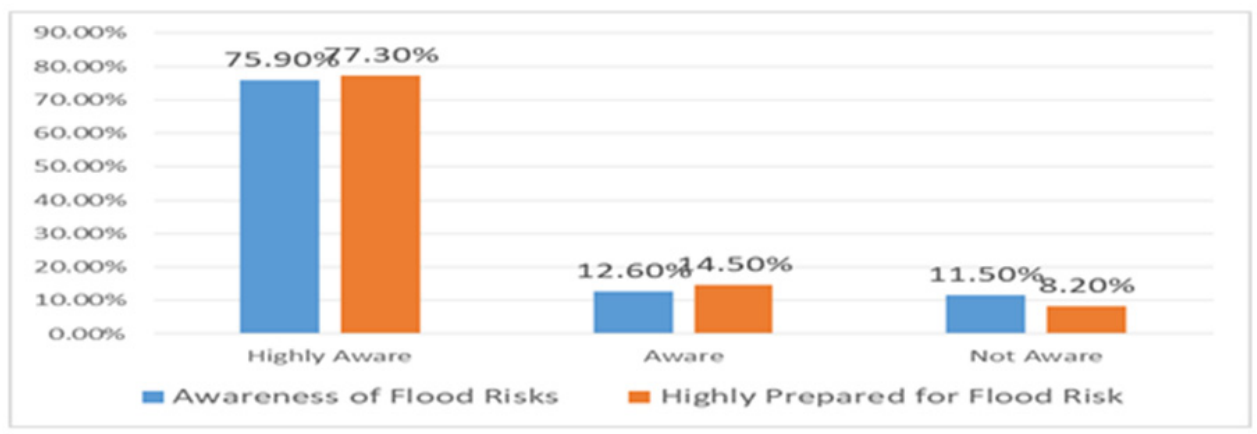

Figure 7: Flood Risks Awareness and Level of Preparedness

Figure 7 indicates that there is a close correlation between awareness of flood risks and level of preparedness supporting the fact that awareness leads to preparedness. It shows that in the case of 75.5 per cent of the respondents that are aware of flood risk, over 77 per cent of them were prepared for flood risks disaster. In the case of 11.5 per cent of the respondents that are not aware of flood risks disaster, only 8.2 per cent were prepared for flood risk disaster. 


\section{Conclusion and Recommendation}

The paper shows that the majority of the respondents were aware of their exposure to flood risks. However, awareness to flood risks is more for respondents that already experienced flooding in the past. It also reveals flood risks worry as one of the key determinants for flood risks preparedness. In addition, it also shows that flood risks preparedness was higher for respondents that were more worried of flood risks disaster and low for respondents that were less worried. It further shows a close but positive correlation between awareness of flood risks and level of preparedness supporting the fact that awareness leads to flood risks preparedness. In the light of the above findings, the paper calls for increase flood risk awareness creation at the community level as key strategy to increase disaster risk preparedness and build community resilience to flood risk disaster in Lagos megacity.

\section{References}

Adeoye, N.O Ayanlade, A. and Babatimehin, O. (2009). Climate Change and Menace of Floods in Nigerian Cities: Socio-economic Implications. Advances in Natural and Applied Sciences, 3(3): 369-377

Brown, J. D. and Damery, S. L. (2002): Managing Flood Risk in the UK: Towards an Integration of Social and Technical Perspectives, T. I.Brit. Geogr. 27, 412-426

Business and Maritime West Africa (2013): Risk of Flood Losses: Lagos Ranked 15th Among Cities Worldwide - Accessed $05^{\text {th }}$ June from http://businessandmaritimewestafrica.com/maritime-news/risk-of-flood-losseslagos-ranked-15th-among-cities-worldwide\#sthash.NQjt8UHr.dpuf

Crichton, D., (1999) The Risk Triangle. In: Ingleton, J. [Ed.]. Natural Disaster Management. Tudor Rose. 102103.

Hansen, W. L. (2005): Income Distribution Effects of Higher Education, American Economic Rev., 60, 335-340, 1970.

International Strategy for Disaster Reduction [ISDR] (2004). Living with Risk: Living with Risk: A Global Review of Disaster Reduction Initiatives. International Strategy for Disaster Reduction United Nations, Geneva, Switzerland.

Jonkman SN. (2005). Global perspectives on loss of human life caused by floods. Natural Hazards, 2005; 34(2):151-175.

Kundzewicz, Z. W.: (1999): Flood Protection Sustainability Issues, Hydrol. Sci. J., 44, 559-571

Onwuemele, A. (2012). Cities in the Flood: Vulnerability and Disaster Risk Management: Evidence from Ibadan, Nigeria: In William G.H (eds.). Urban Areas and Global Climate. Research in Urban Sociology, Vol. 12, Emerald Publishing Group, Howard House, UK. pp. 277-299. ISBN (978-1-78190-036-9)

Pagneux, E., G'islad'ottir, G., and J'onsd'ottir, S. (2011): Public Perception of Flood Hazard and Flood Risk in Iceland: A Case Study in a Watershed Prone to Ice-jam Floods, Nat. Hazards, 58, 269-287, 2011

Raaijmakers, R., Krywkow, J. R., and van der Veen, A. (2008): Flood Risk Perceptions and Spatial Multi-criteria Analysis: An Exploratory Research for Hazard Mitigation, Nat. Hazards, 46, 307-322

Samuels, P. \& Gouldby, B. (2009) Language of Risk - Project Definitions (Second Edition), FloodSite Consortium, T32-04-01, http://www.floodsite.net/html/partner_area/project_docs/T32_04_01_FLOODsite LLanguage_of_Risk_D32_2_v5_2_P1.pdf

Siegrist M, Gutscher H. (2006) Flooding Risks: A Comparison of lay People's Perceptions and Expert's Assessments in Switzerland. Risk Analysis; 26 (4):971-979.

Slovic, P. (2000): The Perception of Risk, Earthscan Publications, London, 2000.

Smith K, Petley DN. (2009). Environmental Hazards. Assessing Risk and Reducing Disaster. London: Routledge; 2009.

Terpstra, T.: (2010): Flood Preparedness: Thoughts, Feelings and Intentions of the Dutch Public, University of Twente,

UN Office for Disaster Risk Reduction (UNISDR) (2016). The Human Cost of Weather Related Disasters 19952015

Wilson, C (1990): Education and Risk, in: Hazards and the Communication of Risk, edited by: Handmer, J. and Penning- Rowsell, E., Gower, England, (1999).

World Meteorological Station/ Global Water Partnership, (WMO/WGP) (2008). Urban Flood Risk Management. A Tool for Integrated Flood Management. APFM Technical Document No. 11, Flood Management Tool Series, WMO.GWP.

Kellens, W., Terpstra, T., Schelfaut, K., De Maeyer, P., 2013. Perception and communication of flood risks: A literature review. Risk Analysis. 33 (1), 24-49. 